\title{
ASPEK ERGONOMI DARI RISIKO PSIKOSOSIAL DI TEMPAT KERJA
}

\author{
Sutjana, I D.P. \\ Bagian Fisiologi FK/PS Magister Ergonomi Program Pascasarjana \\ Universitas Udayana Denpasar Bali. E-mail: idp_sucana@yahoo.com
}

\begin{abstract}
ABSTRAK
Perkembangan ilmu pengetahuan dan teknologi (IPTEK) sangat pesat beberapa dekade terakhir ini telah terbukti memberikan manfaat yang sangat besar bagi kesejahteraan masyarakat, namun tanpa disadari juga menimbulkan dampak negatif seperti meningkatnya keluhan, penyakit akibat kerja, kecelakaan kerja, maupun stres. Disamping itu di era global para pekerja menghadapi $3 \mathrm{C}$ (complexity, competition, changes), sehingga dituntut selalu harus mengikuti perkembangan IPTEK, kalau tidak akan ditinggal dan pasti akan selalu ketinggalan. Pada kondisi demikian itu bagi yang kurang mampu mengikuti perkembangan akan mengalami kegelisahan yang diikuti dengan stres sebagai salah satu risiko psikososial dengan segala akibatnya. Oleh karena masalah yang dihadapi makin kompleks dengan persaingan yang makin ketat maka gejala gangguan psikososial itupun makin meningkat. Gangguan psikososial akan menimbulkan berbagai keluhan yang diikuti penurunan produktivitas kerja, bahkan bisa menimbulkan kecelakaan kerja. Ergonomi sebagai pendekatan multi/interdisiplin, dimana disiplin psikologi merupakan bagian dari pendekatan ergonomi juga membahas risiko psikososial yang dihadapi pekerja. Ergonomi berupaya menciptakan kondisi kerja yang sehat, aman, nyaman, efektif dan efisien atau serasi dengan pekerja untuk meningkatkan produktivitas dan kesejahteraan pekerja. Dalam hal ini diupayakan adanya keserasian antara task, organisasi dan lingkungan kerja terhadap kemampuan, kebolehan dan batasan manusia, sehingga seseorang mampu bekerja dengan maksimal, dengan risiko yang minimal, termasuk risiko psychosocial. Jadi semua aspek ergonomi tersebut juga merupakan faktor yang bisa menimbulkan risiko psycholsosial. Komponen dari task seperti jenis pekerjaan, beban kerja, tanggung jawab merupakan aspek ergonomi, juga sebagai faktor yang dapat menimbulkan risiko psikososial. Organisasi seperti pengaturan giliran kerja, jam kerja dan jam istirahat, hubungan antara pekerja atau dengan atasan atau bawahan, sistem penggajian, penghargaan dan sangsi, demikian juga faktor lingkungan kerja seperti faktor sosial, perbedaan ras, etnis, budaya, agama adalah aspek ergonomi yang merupakan faktor yang dapat menimbulkan risiko psychsosial. Apabila ditinjau dari pendekatan ergonomi total dimana dibahas hubungan pekerja dengan task, organisasi dan lingkungan kerja maka aspek ergonomi hampir sama dengan faktor risiko psikososial.
\end{abstract}

Kata kunci: risiko psikososial, aspek ergonomi, ergonomi total. 


\section{PENDAHULUAN}

Beberapa dekade terakhir perkembangan ilmu pengetahuan dan teknologi (IPTEK) sangat pesat di semua sektor kehidupan masyarakat. Dengan perkembangan IPTEK yang begitu pesat telah terbukti memberikan manfaat yang sangat besar bagi kehidupan manusia yang diikuti peningkatan produktivitas maupun kesejahteraan masyarakat. Namun tanpa disadari perkembangan IPTEK juga menimbulkan dampak negatif seperti meningkatnya keluhan, penyakit akibat kerja, kecelakaan kerja, maupun stres.

Disamping menghadapi perkembangan IPTEK yang begitu pesat dalam era global semua orang menghadapi $3 \mathrm{C}$ (complexity, competition, changes), sehingga dituntut selalu harus mengikuti perkembangan IPTEK, kalau tidak akan ditinggal dan pasti akan selalu ketinggalan (Manuaba, 2004). Dengan kondisi demikian itu maka bagi yang kurang mampu mengikuti perkembangan akan mengalami kegelisahan yang diikuti dengan stres sebagai salah satu risiko psikososial dengan segala akibatnya. Oleh karena masalah yang dihadapi makin kompleks dengan persaingan yang makin ketat maka gejala gangguan psikososial itupun makin banyak dan makin sulit dikenal, sehingga sering kurang disadari dan penanganannya sering kurang tepat. Gangguan psikososial bisa terjadi pada semua orang baik yang kaya, miskin, yang berpendidikan maupun bukan, yang beban kerja berat maupun yang beban kerjanya tampak ringan. Yang jelas timbulnya gangguan psikososial tersebut akan menimbulkan berbagai keluhan yang diikuti penurunan produktivitas kerja, bahkan bisa menimbulkan kecelakaan kerja.

Ergonomi sebagai pendekatan multi/interdisiplin juga membahas mengenai masalah psychosocial yang sering dihadapi para pekerja. Ergonomi berupaya menciptakan kondisi kerja yang sehat, aman, nyaman, efektif dan efisien atau serasi dengan pekerja untuk meningkatkan produktivitas dan kesejahteraan pekerja. Dalam hal ini diupayakan adanya keserasian antara tugas dan kapasitas kerja seseorang sehingga orang tersebut mampu bekerja dengan maksimal, dengan risiko yang minimal, termasuk risiko psikososial (Grandjean, 1993; Manuaba, 2004; WiderszalBazyl, 2010; Sutjana, 2011). Dalam ergonomi membahas hubungan pekerja (manusia) dengan alat kerja, cara, organisasi kerja maupun lingkungan kerjanya di tempat kerja.

Ergonomi sebagai pendekatan multi/interdisiplin dimana disiplin psikologi merupakan disiplin yang juga berkontribusi dalam memecahkan masalah ergonomi, jelas aspek ergonomi juga merupakan faktor yang menimbulkan risiko psikososial. Dan masalahmasalah psikososial juga merupakan masalah ergonomi yang perlu mendapatkan pemecahan melalui pendekatan ergonomi.

Dalam makalah ini akan dibahas faktorfaktor ergonomi dari risiko psikososial di tempat kerja yang akhir-akhir ini menimbulkan masalah di berbagai tempat kerja, dengan berbagai risiko yang jelas merugikan baik bagi pekerja sendiri, pengusaha maupun masyarakat. Oleh karena itu upaya untuk mengidentifikasi faktor-faktor penyebab timbulnya risiko psikososial perlu diketahui sedini mungkin, guna meminimalkan risiko yang mungkin timbul.

\section{FAKTOR PSIKOSOSIAL}

Faktor psikososial sering dinyatakan dengan bagaimana pandangan pekerja maupun manajer terhadap organisasi kerja yang dilaksanakan di tempat kerjanya. Organisasi kerja dilaksanakan di tempat kerja adalah untuk melaksanakan proses produksi, yang harus diikuti oleh para pekerja, pengawas, mandor maupun para manajer.

NIOSH (dalam Erez dan Lindgren, 1999), menyatakan bahwa faktor psikososial sebagai istilah umum menetapkan beberapa variabel menjadi tiga kategori:

1. Faktor yang berkaitan dengan lingkungan kerja/organisasi kerja 
2. Faktor yang berkaitan dengan faktor di luar lingkungan kerja

3. Faktor yang berasal dari karakteristik individu pekerja sendiri

Ketiga faktor tersebut dapat menimbulkan risiko psikososial tergantung dari keseimbangan antara tugas dan kapasitas kerja yang dimiliki pekerja tersebut. Adapun risiko yang mungkin timbul antara lain sbb.

Ad 1. Faktor risiko yang berkaitan dengan lingkungan kerja/organisasi kerja, meliputi:

a. Karakteristik dari tugas yang dihadapi (beban kerja, repetisi, mental demand)

b. Struktur organisasi (komunikasi antara pekerja)

c. Hubungan interpersonal di tempat kerja (hubungan antara pekerja, dengan supervisor, dengan pembantu)

d. Aspek temporal dari pekerjaan (giliran kerja, pertukaran giliran kerja, waktu kerja dan wakktu istirahat)

e. Financial dan aspek ekonomi (perbedaan upah pada tugas yang sama, pembagian keuntungan, reward and punishment)

f. Sistem nilai di masyarakat (prestige, status)

Ad 2. Faktor di luar lingkungan.

Faktor ini berasal dari luar tempat kerja tetapi sangat mempengaruhi kenyamanan kerja di tempat kerja atau perusahaan. Faktor ini datang dari luar kemampuan pekerja maupun manajer, tetapi memberi dampak sangat besar, bahkan bisa merusak tatanan kerja yang sudah diciptakan secara harmonis. Faktor tersebut dapat berupa:

a. Policy pemerintah maupun perubahan global,

b. Gangguan keamanan,

c. Penyakit menular yang menyerang masyarakat banyak,
d. Tuntutan konsumen.

Ad 3. Faktor karakteristik individu dari pekerja

Faktor ini berkaitan dengan individu masing-masing yang berbeda satu dengan lainnya. Perbedaan tersebut tergantung pada:

a. Genetik (gender, intelejensi, kepercayaan)

b. Ecquired (klas sosial, budaya, pendidikan)

c. disposisi (personality, pandangan hidup)

Berlawanan dengan NIOSH, maka ILO, WHO (dalam Erez dan Lindgren, 1999), dalam laporan bersamanya menyatakan bahwa faktor psikososial yang berkaitan dengan pekerjaan dibedakan dalam lima kategori, sbb.

1. Dalam kategori ini lingkungan fisik

2. Intensitas dari tugas (workload, work design)

3. Pengaturan dari waktu kerja (lama kerja, shift work)

4. Management or operating practices (SOP pekerja, hubungan antara pekerja)

5. Perkembangan atau perubahan teknologi

tidak mencakup faktor di luar pekerjaan dan perbedaan dari masing-masing pekerja.

Dari pernyataan NIOSH maupun ILO/WHO tersebut maka timbul pertanyaan: "Yang manakah termasuk aspek ergonomi? Apabila ditinjau dari definisi ergonomi pada awalnya atau sering disebut ergonomi mikro yang hanya membahas masalah kenyamanan meja dan kursi saja, maka sepertinya tidak ada aspek ergonomi dari faktor risiko psikososial. Bahkan ada yang mengatakan bahwa faktor psikososial tidak ada kaitannya dengan ergonomi. Namun apabila ditinjau dari definisi ergonomi sekarang (ergonomi mikro dan makro), maka ergonomi bukan sekedar mendesain meja dan kursi yang nyaman, tetapi jauh lebih luas daripada itu. 


\section{DEFINISI ERGONOMI}

"Ergonomi adalah suatu pendekatan multi /interdisiplin yang berupaya menserasikan alat, cara dan lingkungan kerja terhadap kemampuan, kebolehan dan batasan manusia untuk menciptakan kondisi kerja yang sehat, aman, nyaman dan efisien untuk meningkatkan produktivitas dan kesejahteraan tenaga kerja“.

Dari definisi tersebut dapat disimak bahwa semua disiplin yang membicarakan manusia dalam beraktivitas baik saat waktu beristirahat, melakukan rekreasi, olahraga lebihlebih lagi pada waktu melakukan pekerjaan akan ikut berkontribusi dalam ergonomi.

Dari definisi tersebut diperoleh juga dapat disimpulkan bahwa ergonomi akan dijumpai pada setiap tempat kerja apalagi manusia harus ada di dalamnya (Sutalaksana,2000). Demikian juga dalam mendesain setiap peralatan kerja mulai dari tusuk gigi sampai pesawat ruang angkasa jelas membutuhkan pendekatan ergonomi agar enak dipakai, nyaman dipakai, efisien dalam pemakaian, mudah dioperasikan, mudah perawatan, murah biaya, tetapi produktivitas yang tinggi serta sedikit menimbulkan risiko. Dengan demikian harapan untuk meningkatkan kesejahteraan tenaga kerja makin mendekati harapan.

Dalam ergonomi berkontribusi berbagai macam disiplin seperti disiplin biologi, anatomi, fisiologi, kesehatan, gizi, antropologi, psikologi, budaya, ekonomi, teknik, fisika, desain, pendidikan, dsb, untuk memenuhi kebutuhan serta kesejahteraan manusia, melalui perkembangan ilmu pengetahuan dan teknologi. Namun perlu disadari perkembangan ilmu pengetahuan dan teknologi di samping memberikan kesejahteraan kepada manusia sering pula menimbulkan dampak negatif yang tidak kita inginkan, seperti timbulnya polusi, bising, vibrasi, keluhan, kecelakaan kerja, penyakit akibat kerja dsb.
Di beberapa negara berbagai sebutan sering dipakai untuk disiplin ergonomi ini antara lain (Grandjean, 1993; Bridger, 2003):

- $\quad$ To fit the task to the man

- The rules of work

- Making the task user friendly

- Human machine interface

- Human engineering

- Human factors

- The scientific study of human work

- The application of scientific information concerning human being to the design of objects, system and environments of human use

- The science of matching the job to the worker and product to the user

Apapun istilah yang dipakai tidaklah begitu penting dipermasalahkan. Yang penting diketahui semua istilah yang dipakai tersebut pembahasannya hampir sama yaitu membahas persoalan manusia sebagai tenaga kerja dalam menghadapi pekerjaan. Semua berupaya meningkatkan hasil kerja, mutu pekerjaan maupun produk, meningkatkan keuntungan dan meminimalkan risiko yang mungkin terjadi. Kemungkinan perbedaannya ada dalam tinjauannya. Jelas sudut pandangnya dari disiplin masing-masing. Oleh karena itu setiap disiplin diharapkan tidak arogan dalam sudut pandangnya, tetapi semua disiplin harusnya bekerja secara terpadu guna menciptakan kondisi kerja yang aman, nyaman, sehat, efisien dan produktif. Melalui ergonomi hal tersebut sangat mungkin dilakukan. Dan penerapan ergonomi sebaiknya dilakukan secara total melalui pendekatan ergonomi total yang merupakan penggabungan penerapan teknologi tepat guna yang diterapkan melalui pendekatan SHIP (systemic, holistic, interdisipline, participatory).

Penerapan teknologi tepat guna adalah penerapan teknologi yang sesuai dengan kebutuhan dan kondisi masyarakat pemakai. Selama ini teknologi tepat guna sering diartikan dengan teknologi yang sederhana, sangat murah. Tetapi sebetulnya bisa yang murah, bisa pula 
yang mahal, yang jelas harus serasi dengan kondisi pemakai. Hal ini sesuai dengan pengertian ergonomi yaitu teknologi yang user friendly. Agar lebih mudah memahami maka teknologi tepat guna dapat disesuaikan dengan kebutuhan masyarakat pemakai, dapat ditinjau dari tujuh aspek (Manuaba, 2004), yaitu:

a. Secara teknis, dimana teknologi yang akan dipakai agar memberikan hasil yang lebih baik, namun dapat dipahami, dimengerti dan dikerjakan oleh pemakai,

b. Secara ekonomis, hasilnya lebih menguntungkan dari yang dipakai sebelumnya, dan terjangkau oleh pemakai,

c. Dari sudut kesehatan, keselamatan maupun ergonomi dapat dipertanggung jawabkan, yang berarti tidak mudah menimbulkan keluhan, gangguan kesehatan dan keselamatan, serta mampu memberikan kenyamanan dalam melakukan pekerjaan,

d. Tidak merusak lingkungan maupun menimbulkan polusi yang dapat merusak lingkungan kerja maupun lingkungan masyarakat,

e. Irit dalam pemakaian energi, karena sumber energi makin lama makin mahal dan makin sulit dicari,

f. Dapat diterima oleh budaya setempat, bukan bahkan merusak budaya masyarakat setempat maupun masyarakat luas,

g. Trendi, yang berarti sesuai dengan perkembangan zaman, maupun kebutuhan global.

Dari pertimbangan tersebut diharapkan penerapan teknologi dapat meminimalkan timbulnya masalah di kemudian hari, tidak merusak lingkungan dan mendukung pembangunan berkelanjutan.

Bagaimana cara agar bisa menerapkan teknologi tepat guna dalam upaya penerapan ergonomi secara total, disini diperlukan pendekatan SHIP. Melalui pendekatan SHIP yang dimaksudkan adalah sbb.

a. Secara sistemik, berarti dalam menerapkan teknologi tersebut semua sistem yang ada di tempat kerja, agar tidak menyalahi prosedur,

b. Secara holistik, dimaksudkan agar semua komponen yang ada di tempat kerja memahami apa yang akan dilakukan serta mengerti apa manfaatnya maupun yang mungkin timbul di kemudian hari,

c. Secara interdisipliner, artinya dalam penerapan teknologi maupun metode baru, agar semua disiplin yang berkaitan harus dilibatkan,

d. Partisipatori, artinya dalam penerapan suatu teknologi maupun metode baru, sebelumnya semua komponen agar dilibatkan untuk ikut memberikan pendapat, memberikan masukan, serta ikut bertanggung jawab dalam pelaksanaannya.

Dengan metode seperti itu diharapkan semua komponen merasa ikut memiliki dan bertanggung jawab, serta merasa dihargai dalam pelaksanaan setiap perbaikan maupun penerapan teknologi maupun metode baru di tempat kerja. Kondisi demikian akan mampu mengurangi faktor-faktor yang menimbulkan risiko psikososial di tempat kerja.

Oleh karena itu dalam penerapannya dimana berkontribusi berbagai disiplin dalam ergonomi sangat tergantung dari faktor-faktor yang ada di tempat kerja yang dihadapi oleh para pekerja. Dari berbagai faktor yang terdapat 
di tempat kerja tersebut, apakah akan memberikan dampak positif atau justru akan menimbulkan dampak negatif pada tenaga kerja tergantung dari keseimbangan antara kebutuhan tugas (task demand) dengan kapasitas kerja (work capacity) tenaga kerja. Keseimbangan tersebut dapat dilihat dari keseimbangan seperti

\section{TUNTUTAN TUGAS/TASK DEMAND}

-karakteristik material
-karakteristik tugas
-karakteristik lingkungan
-karakteristik organisasi
Gambar 1.

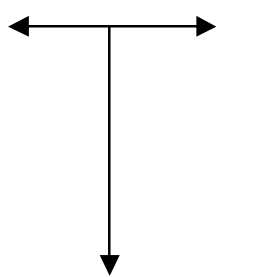

KAPASITAS KERJA/WORK CAPACITY

-kapasitas personal

-kapasitas fisiologis

-kapasitas psikologis

-kapasitas biomekanis

KINERJA/PERFORMANCE

-kelelahan/keluhan

-stres/kecelakaan/penyakit

-kenyamanan/efisien/produktif

-mutu baik/cacat

Gambar 1. Konsep Keseimbangan Ergonomi (Manuaba, 2004)

Apabila dilihat dari konsep keseimbangan tersebut maka faktor psikososial termasuk dalam komponen kapasitas kerja yang diperhatikan dalam ergonomi. Faktor psikososial menentukan apakah keseimbangan tersebut menghasilkan kinerja yang maksimal atau justru akan menimbulkan risiko. Apabila terjadi ketidakserasian antara tuntutan tugas dengan kapasitas kerja akan timbul dampak negatif atau risiko, mulai dari cepat timbulnya rasa lelah, keluhan muskuloskeletal, kecelakaan, penyakit akibat kerja dsb, yang pada akhirnya diikuti dengan penurunan produktivitas, keuntungan dan kesejahteraan.

\section{ASPEK ERGONOMI}

Dalam penerapan prinsip ergonomi di tempat kerja dilihat tiga aspek yaitu task, organisasi dan lingkungan diserasikan dengan kemampuan, kebolehan dan batasan manusia sebagai tenaga kerja (Bridger, 2003; Manuaba, 2004). Disini cara pengelompokannya yang sedikit berbeda. Apabila ditinjau dari tiga aspek ergonomi tersebut dikaitkan dengan faktor psikososial di tempat kerja yang dikemukakan oleh NIOSH maupun oleh ILO dan WHO, maka aspek ergonomi dari risiko psikososial adalah sbb.

1.Task atau tugas yang diberikan kepada pekerja.

Dari tugas yang diberikan tersebut berbagai hal bisa terjadi yang bisa menimbulkan risiko psikososial. Untuk memahami tugas yang dihadapi para pekerja, selalu harus memperhatikan alat, cara yang dipakai dalam melaksanakan tugas tersebut, yang kemudian menunjukkan karakteristik tugas yang dihadapi, seperti:

a. Beban kerja; beban yang terlalu berat (overload), yang cepat menimbulkan keluhan cepat lelah, keluhan muskuloskeletal, kecelakaan, penyakit akibat kerja. Beban yang ringan (underload) menimbulkan kebosanan, kurang waspada, akan cepat menimbulkan stres, kecelakaan kerja.

b. Pekerjaan dengan repetisi, cepat menimbulkan rasa lelah, keluhan otot, ketegangan. 
c. Membutuhkan tanggung jawab yang tinggi (beban mental)

\section{Organisasi}

a. Struktur organisasi

Koordinasi antara komponen organisasi, komunikasi antara pekerja dalam pelaksanaan organisasi. Ada bagian yang sibuk sementara bagian lain santai, ada yang selalu diberikan peringatan keras sementara yang lain tidak pernah diperingatkan walaupun berbuat salah, dsb.

Demikian pula dalam pengaturan giliran kerja. Para pekerja hidup bermasyarakat setelah pulang kerja, sehingga penerapan giliran atau jam kerja secara ketat sering menimbulkan konflik dan mengarah pada risiko psikososial.

b. Hubungan interpersonal di tempat kerja (hubungan antara pekerja, dengan supervisor, dengan pembantu) yang kurang harmonis akibat dari pelaksanaan tugas.

c. Aspek temporal dari pekerjaan;

1) shift work, pengaturan shift work: dua shift (@12 jam) atau tiga shift(@8jam)

2) cycle time, pengaturan giliran kerja: model 2-2-2, 2-2-3 atau 7-7-7

3) work and rest period, berapa jam kerja dan berapa jam istirahat, kapan istirahat

d. Financial dan aspek ekonomi

1) perbedaan upah (salary) dengaan tugas yang sama akan menimbulkan iri hati, sakit hati dan diikuti ketegangan mental, berkurangannya kenyamanan kerja

2) benefit, pembagian keuntungan yang tidak serasi dengan perjanjian

3) reward and punishment yang lemah, sering menimbulkan stres mental

e. Sistem nilai di masyarakat (value image)
1) prestige sebagai pekerja kasar sangat rendah seperti pedagang acung, sales keliling kurang prestigenya, dibandingkan dengan PNS yang memiliki prestige yang tinggi

2) status kepegawaian, tenaga kontrak (outsorcing) dibandingkan dengan tenaga tetap

\section{Faktor Lingkungan}

Lingkungan di tempat kerja berasal dari berbagai faktor seperti lingkungan fisik, kimia, biologi, psikologi dan sosial budaya. Dalam hal ini aspek ergonomi yang berkaitan dengan faktor psikososial antara lain.

a. Hubungan sesama pekerja baik dengan atasan, bawahan.

b. Perbedaan perlakuan dengan perbedaan ras atau etnis pada jenis pekerjaan yang sama, akan menimbulkan gangguan dalam pelaksanaan tugas, dengan berbagai akibatnya.

c. Adanya perbedaan kesempatan promosi atau peningkatan karier, pemberian sanksi dan penghargaan.

Di samping itu faktor lingkungan dari luar tempat kerja, juga akan berpengaruh terhadap kondisi kerja, seperti:

a. Policy pemerintah maupun krisis global, seperti kebijakan keuangan, batasan eksport produk ke negara tertentu yang bermasalah dengan Indonesia, krisis keuangan global seperti tahun 1998, hampir semua perusahaan kena dampaknya, dan akan diikuti oleh kebijakan perusahaan. Sudah jelas ini sangat menimbulkan masalah psikososial.

b. Gangguan keamanan seperti peristiwa bom Bali tahun 2002 dan 2005 yang lalu, hampir semua perusahaan hotel dan restoran, 
industri kecil ikut kena dampak, sehingga para tenaga kerja yang sangat menderita dampak psikososial.

c. Penyakit menular yang menyerang masyarakat banyak. Penyakitpenyakit menular yang mudah menular seperti penyakit SARS, pengaruhnya lebih buruk dari akibat bom.

d. Persyaratan yang dituntut oleh konsumen, seperti produk halal, pelaksanaan K3 di perusahaan, dsb. Bagi yang tidak mampu memenuhi persyaratan tersebut akan mengalami kesulitan mulai dari penurunan pesanan, yang berarti pekerjaan berkurang, penghasilan karyawan berkurang sampai pemutusan hubungan kerja.

4. Faktor individu, sebagai kondisi pekerja sendiri yang akan berinteraksi dengan kedua faktor di atas

memiliki kemampuan, kebolehan dan batasan serta sistem nilai masing-masing. Faktor ini berkaitan

dengan individu masing-masing yang berbeda satu dengan lainnya, seperti:

a. Genetik (gender, intelejensi, kepercayaan). Memang setiap orang berbeda baik kemampuan fisik maupun kemampuan mental. Juga dari sudut intelejensia dan kepercayaan yang diyakininya. Oleh karena itu semua faktor tersebut harus diperhatikan jangan sampai menimbulkan friksi.

b. Ecquired (klas sosial, budaya,pendidikan, keterampilan, pengalaman). Kondisi tenaga kerja harus selalu diperhatikan seperti klan, (dari golongan brahmana, ksatria) sering sangat berpengaruh. Demikian juga budaya setempat, pendidikan, keterampilan maupun pengalaman penting sekali mendapatkan perhatian. Paling tidak dipakai dalam menentukan kenaikan jabatan maupun dalam penilaian lainnya.

c. Disposisi (personality, pandangan hidup), masing-masing tanaga kerja sering memiliki pandangan hidup masing-masing. Ada yang ingin mencari pengalaman seluas-luasnya, ada pula yang ingin mencari uang tidak memikirkan apapun jenis pekerjaannya asal uangnya banyak. Ada pula yang mempunyai pandangan asal di Bali walaupun gajinya kecil dsb.

\section{SIMPULAN}

Dari uraian di atas dapat disimpulkan bahwa beberapa aspek ergonomi juga merupakan faktor-faktor yang merupakan atau bisa menimbulkan risiko psikososial. Hal bisa dipahami karena disiplin psikologi juga merupakan disiplin yang berkontribusi dalam pendekatan ergonomi yang merupakan pendekatan multi/interdisiplin.

Hanya perlu disadari bahwa apabila membahas dari sudut pandang pekerja itu sendiri maka akan tampak merupakan risiko psikososial. Tetapi apabila masalah yang dihadapi tenaga kerja di tempat kerja, karena selalu akan berkaitan dengan task, organisasi dan lingkungan kerja maka masalah tersebut merupakan aspek ergonomi, yang risikonya sebagai risiko psikososial.

Jadi masalah-masalah yang bisa menimbulkan risiko psikososial yang ada kaitannya dengan task, organisasi dan lingkungan kerja merupakan aspek ergonomi.

\section{RUJUKAN}

Bridger, R.S. 2003. Introduction to Ergonomics. 2nd Edition. London: Tylor and Francis.

Erez, A.B; Lindgren, K.N. 1999. Psychosocial

$\begin{array}{lr}\text { factors in } & \text { Work-Related } \\ \text { Musculoskeletal } & \text { Disorders. }\end{array}$


Ergonomics for Therapists. Second Edition.Edited by. Karen Jacobs.Utterworth. Boston.

Grandjean, E. 1993. Fitting the Task to the Man. A Textbook of Occupational Ergonomics. $4^{\text {th }}$ Ed. London. Taylor \& Francis

Manuaba, A. 2004. Holistic Ergonomics Approach is a Must in automation to attain humane, competitive and sustainable work process and products. Seminar Ergonomi Nasional dengan thema" Application of Ergonomics in Industry" UPN Yogyakarta. 27 Maret.

Sutalaksana, I.Z. 2000. Peningkatan Produktivitas dengan Penerapan Ergonomi. Konvensi K3 2000. Di Jakarta, 18-20 Januari.

Sutjana, I D.P. 2011. Jam Kerja Fleksibel Menurunkan "Turnover" Karyawan. $11^{\text {th }}$ National Conference of Indonesian Ergonomics Society 2011 dan Industral Ergonomics Workshop. 14-15 September. Jakarta.

Sutjana, I D.P.; Adiputra, N. 2005. Unsafe Act as The Risk Factors of Accidents in Using Mill In Roof Tile Industry at Pejaten Village Tabanan Regency. Presented in International Conference on Occupational Health Aspects of Industrial Development and Informal Sector 2005. Nov.29-Dec 1, Yogyakarta.

Widerszal-Bazyl, M.2010. Psychosocial Risk in the Workplace and Its reduction. Handbook of Occupational Safety and Heal 